\title{
The Effectiveness of Note-Taking on Reading Comprehension of Iranian EFL Learners
}

Farnoush Bahrami*, Heidar Nosratzadeh

Department of English Language, Damavand Branch, Islamic Azad University, Damavand, Iran

Corresponding Author: Farnoush Bahrami, E-mail: farnoosh.bahrami@chmail.ir

\section{ARTICLE INFO}

\section{Article history}

Received: June 12, 2017

Accepted: August 25, 2017

Published: December 01, 2017

Volume: 6 Issue: 7

Special Issue on Language \& Literature

Advance access: September 2017

Conflicts of interest: None

Funding: None

\begin{abstract}
By taking notes students could save time for reading all textbooks for their exams or for their representations. Taking notes increases attention of students to read or heard materials, and this increases their comprehension. Thus, the present study is important because note-taking could help them to remember what they learnt, absolutely important information. The method used in this research was survey. The 40 Persian EFL learners were selected from a language institute in Karaj to participate in the present study. These learners were divided into two groups; one of them is experimental group $(\mathrm{N}=20)$ and the other one is control group $(\mathrm{N}=20)$. Pretest and post test were two instruments that were used to carry out this study, a pretest about skill of notetaking of passages of the lessons was used for both experimental and control group. This test consisted of 4 passages. The same test was administrated again as the post test for both groups by the end of the course to see the different conclusion between taking note of experimental group and control group. Reliability between 4 texts is in oscillation from 0.6 to 0.81 (from 0.6 upwards). Therefore this reliability was an acceptable one. To analyze data descriptive statistics (that was contained percentage, frequency and mean score) and also inferential statistics (that was contained ANOVA, Pearson correlation, independent sample t-test, multivariate's test, regression) were carried out by using SPSS16 software. The findings confirmed that note taking is effective in reading comprehension.
\end{abstract}

Key words: Note Taking, Reading Comprehension, Text, EFL Learners

\section{INTRODUCTION}

Learning English has become really important to most the Iranian students. Knowing English has been considered as an enabler to open doors to success nationally and internationally. Students from various disciplines and fields need to learn English to increase their knowledge or gather information in their field. Therefore they need to read and understand English books and articles to catch up with advanced knowledge. Learning a second language is an important need for almost all the people to communicate with each other. The role of reading comprehension is essential for students in their academic achievement whereas first line information and advancement in technology and knowledge normally published in English.

Reading is a complicated mental activity in which the reader predicts or verifies the information conveyed in the text by using previous experience, information or knowledge and also an interaction between both reader and writer through the text where the main outcome would be comprehension by Yu-hui and Zhu and Nian (2010).
In short, reading comprehension is a process through which an individual tries to understand and explore the meaning/ message laid in a text explicitly or implicitly through using some strategies that help us to comprehend better, for intense; by asking question, combination, imagination, presumption, and guessing according to Harvey \&Goudvis (2000), among which making inference has been important in recent modern years. When we talk about reading comprehension we broadly realized that it deals with the reader's understanding about the texts she reads and also her knowledge about linguistics. According to Field (2002),when reader is reading a given topic, she deals with some fundamental aspects of comprehending and realizing the text. It means that she thinks what the exact meaning of a word, what the special meaning it has in the specific sentence or text; because one of the important things about reading is meaning the idea that laid in the text, and also how reader constructs the information in her mind because this is a mental process. One of the important keys that enhance the comprehension is reviewing the note which amplifies thoughts. According to Kobayashi (2005), we could say that taking notes is the important instrument that helps us better comprehending. 
Unfortunately just some students know about how they must taking effective notes and they are intended to know how to take comprehensive notes during their terms notwithstanding teaching them how to do it correctly. Unfortunately, only some students know how to make effective note-taking; although they are not trained, they are asked to take comprehensive and accurate notes during their semesters. Note taking is a necessary instrument that helps students to gathering information from the texts they read to save the information in their mind better, because students may have to memorize them and need them later. According to Benton and Kim and Christensen (1995), summarizing our notes will more beneficial if first we highlight fundamental words, sentence, or phrases in the given text then rewriting them in our way. Note taking makes students interested to the lesson and cause them read more carefully and do not be inattentive in the class and they will be more focused on the sorting and coding of the context' information, according to Piolat and Olive (2004). Just as any other study, this research will probably suffer from the following limitations:

1. The learners who participated in this study will be selected on the basis on random availability. The researcher wish she has access to a larger population to draw more reliable data, but that will not be possible due to the lack of time and manpower.

2. The researcher can only conduct the research during limited time with determinate tasks for treatment of experimental group. More tasks and a longer period during treatment will lead to more valid and reliable data. In order to obtain more authentic and reliable data, the researcher will apply the following delimitations.

1. The researcher will focus on specified learners only in this study. 2. The researcher will eliminate gender, and social status as factors to be considered in this study.

The aim of this study is to investigation on which does taking notes have significant effect on reading comprehension of Iranian EFL students?

\section{EMPIRICAL STUDIES}

We should add this fact that by taking notes students could save the important information, remember the examples and critical points in their mind very properly, according to Marsh and Sink (2010). When we take notes we should attention to some points. First, notes must be so comprehensive and concise that not only the reader save time, but also capture the whole concept of the text when reviewing it. Notes must also be so simple and understandable that remain in the memory, so we can use it wherever it is needed. Just taking note of the details cannot be used as much as our own personal notes. At the end, students can show a lack of self-awareness if they think that they take proper notes, according to Bonner and Holliday (2006). Researches in an American university among Chinese EFL students shows that having academic skill of taking notes in during the course improve comprehension and enhance their knowledge of their lessons by better recording the information in their mind.According to one research in 2002 note-taking from lectures is widely granted as an effi-cient strategy that helps students to pay more attention and record academic discourse in their mind.

Note taking in unintentionally interesting and focused by the lecture listener and mainly viewed as facilitation of learning and remembrance process for lecture materials. Ac-cording to one study in 1989, note-taking is useful for two main reasons. First, note-taking helps learning a lecture by stimulating focusing ability and engagement of the learner's cognitive processes, such as coding, synthesizing, integrat-ing, and transformation of aural information into meaningful inputs. Second, it is believed a useful act because those taken notes provide a data base of information that later helps the learner in revising and reviewing to recall the information heard in the lecture. One researcher in 1988 maintained that taking lecture notes facilitates recording the lecture content that is found out by examinees.
Roy et al. (2014) who reported that applications of note taking precisely increase the ability of reader in taking note and help them to remember some details and also increase their proficiency in listening, so it is beneficial to be used in language learning classrooms. Marzano, Pickering, \& Pollock (2001) indicating that ef-fective summarizing and note taking lead to an increase in student learning. Helping students recognize how informa-tion is structured would help them summarize what they read or hear. Students who can effectively summarize learn to synthesize information, a higher-order thinking skill which includes analyzing information, identifying key concepts, and defining extraneous information.

In past years studies show that learning note-taking strat-egies improve students' reading skills and precisely are use-ful to make progress in reading tasks of their lessons (O'Mal-ley \& Chamot, 1990; Carrel, 1998; Taraban, 2004; Phakiti, 2006; Motallebzadeh \& Mamdoodi, 2011). For instance, one study in 2005 showed that taking note was beneficial in high-er achievement and also effective to remember the contents that students read.

Earlier studies show that note taking does not solely require a quick hand but also an operative mind, which not only influenced by the language but also on the proficiency level of the learner as well. Taking note in English helps the learner to have better chances in making connections, organizing thoughts, and developing ideas. While working together seems familiar to learners, writing down notes can help reading comprehension in different and broader ways. One study in 2005 showed that taking note was beneficial in higher achievement and also effective to remember the contents that students read.

Data analyses show significant and positive results from note taking analyses which prove students' lecture notes have both quantity and quality. For instance, in two unpublished dissertations, a significant relationship has been reported between Taking notes and reading comprehension.

These studies showed that high level of comprehension of the reading texts significantly deal with the high quality of notes.

Some of the prior researches, however, have not the same opinion as almost all researches which done.

\section{DEFINITION OF THE KEY WORDS}

\section{Note-taking}

Dustin Wax (2007) defines note-taking strategies as those strategies which almost get not taught and teachers believe that someone else must teach how to take notes to students.

Dewitt (2007), stated that note taking is a short piece of information about content to be kept in mind. Taking notes allows for just two strategies in processing the context's information in the mind thus students can taking notes and wrote down their own words and beliefs. students also are able to apply the written words and their ideas. Recovery of the information will be more possible when students write and think simultaneously.

\section{The Act of Taking Note}

note-taking is a complex action derived from physical and mental behaviors which occurs under pressure of time constraints. 
This activity includes comprehension of aural input, identification of essential information, and also storing them. It is noteworthy that working memoryplays a key role in this practice (Piolat et al., 2005).

\section{What is the Reading Comprehension?}

It is the process of constructing meaning in mind when we involve with the content, according to Rand (2002).

\section{Research Hypothese}

Note-taking does not have effect on reading comprehension on Iranian EFL learners.

\section{METHODOLOGY}

The method used in this research was survey.40 Persian EFL learners were selected from a language institute in Karaj to participate in the present study. Majority of them had bachelor's degree and very few of them had MA and associate's degree. All of the participants were learning English as a second language at the level of upper intermediate at the average age of 22 . Both female $(n=30)$ and male $(n=10)$ learners participated in this research. They were divided into two separate groups which one of them is experimental with 20 numbers and the other one is control group with 20 numbers as well.

Two Pretest and posttest were two instruments that were used to carry out this study, a pretest about skill of note-taking of passages of the lessons was used for both experimental and control group. This test consisted of 4 passages. The same test was administrated again as the post test for both groupsby the end of the course to see the different conclusion between taking note of experimental group and control group.

Cases were 40 students, these cases were put into two Separate groups, 20 numbers of them in the experimental group and others in the control group. The researcher conducted this research in 4 sessions and via each session 1 lesson was presented to both experimental and control group. To having reliable data, the researcher will add the following delimitations. 1 . The researcher will teach note-taking strategies to specified students only in this research. 2. The researcher will not work on social status, and also gender. For this present study, some reading materials which were passages about every subject were extracted from authentic reading passages such as Passages 1 at upper- intermediate level. These texts contained information about different subjects. Four parallel tests of reading comprehension were prepared focusing on proper note taking. The tests consisted of some reading comprehension passages accompanied by multiple-choice item questions. Two pre-tests and two posttests were used. Reliability index of the reading comprehension test was determined using Cronbach alpha.

In Table 1- reliability of the test mentioned based on Cronbakh Alpha. As it seems reliability between these 4 texts is in oscillation from 0.6 to 0.81 (from 0.6 upwards). Therefore this reliability is an acceptable one. To analyse data descriptive statistics (that was contained percentage, frequency and mean score) and also inferential statistics (that was contained ANOVA, Pearson correlation, independent sample t-test, multivariate's test, regression) were carried out by using SPSS16 soft ware.

\section{FINDINGS}

\section{Description of Given Data}

With due attention to what has shown in Table 2, 40 persons of sample group equally stand in both experimental and control group (each group 20 persons $(\% 50)$.

With due attention to what has shown inTable 3- majority of experimental group (16 persons equivalent \%80) and control group (15 persons equivalent \%75) are females and the rest are males.

With due attention to what has been shown in Table 4 majority of experimental group (10 persons equivalent $\% 50$ ) and control group (8 persons equivalent \%40) have Bachelor's degree. This is whereas just \%20 of experimental group and $\% 25$ of control group have Associate's degree.

As represented in the Table 5, the mean of pretest of experimental group in passages 1 to 4 is respectively (3.15, $2.5,3.3$ and 4$)$ and in control group is $(3.2,2.6,3.2,3.95)$, as we see mean of marks of both groups in pretest and posttest are so close to each other.But mean of posttest experimental group in passages 1 to 4 respectively is $(7.1,8,7.4$ and 7.85$)$ and in control group is $(3.5,2.7,3.33 .9)$, therefore we could say: mean of posttest marks of experimental group shows increase over control group.

With due attention to the Table 6 , mean of marks which was reported of persons with associate degree is (7.5), bachelor's degree is (7.875) and M.A. degree is (7.16).

As we see in Table 7- with $\operatorname{Sig}>0.05$, F $(2,17)=0.768$ Indicated that there is no significant difference among marks

Table 1. Reliability of test

\begin{tabular}{lccc}
\hline & Alpha & & Alpha \\
\hline Text1 & 0.62 & Text3 & 0.73 \\
Text2 & 0.6 & Text4 & 0.81 \\
\hline
\end{tabular}

Table 2. Groups

\begin{tabular}{lccc}
\hline Group & Frequency & Percent & $\begin{array}{c}\text { Cumulative } \\
\text { percent }\end{array}$ \\
\hline Examination & 20 & 50 & 50 \\
Control & 20 & 50 & 100 \\
\hline
\end{tabular}

Table 3. Gender

\begin{tabular}{lcccc}
\hline Group & Sex & Frequency & Percent & $\begin{array}{c}\text { Cumulative } \\
\text { percent }\end{array}$ \\
\hline Examination & Girl & 16 & 80 & 80 \\
& Boy & 4 & 20 & 100 \\
Control & Girl & 15 & 75 & 75 \\
& Boy & 5 & 25 & 100 \\
\hline
\end{tabular}


Table 4. Education

\begin{tabular}{llccc}
\hline Group & Education & Frequency & Percent & Cumulative percent \\
\hline Examination & Association degree & 4 & 20 & 20 \\
& Bachelor & 10 & 50 & 70 \\
\multirow{3}{*}{ Control } & MA & 6 & 30 & 100 \\
& Association degree & 5 & 25 & 25 \\
& Bachelor & 8 & 40 & 65 \\
\hline
\end{tabular}

Table 5. Research variable descriptive statistic

\begin{tabular}{|c|c|c|c|c|c|c|c|}
\hline Group & Variable & $\mathbf{N}$ & Minimum & Maximum & Mean & Standard deviation & Variance \\
\hline \multicolumn{8}{|c|}{ Examination } \\
\hline \multirow[t]{2}{*}{ Text1 } & Pre test & 20 & 0 & 8 & 3.15 & 2.059 & 4.239 \\
\hline & Post test & 20 & 5 & 10 & 7.1 & 1.71372 & 2.937 \\
\hline \multirow[t]{2}{*}{ Text2 } & Pre test & 20 & 0 & 8 & 2.5 & 2.13985 & 4.579 \\
\hline & Post test & 20 & 6 & 10 & 8 & 1.71679 & 2.947 \\
\hline \multirow[t]{2}{*}{ Text3 } & Pre test & 20 & 0 & 8 & 3.3 & 2.17885 & 4.747 \\
\hline & Post test & 20 & 0 & 10 & 7.4 & 3.25091 & 10.568 \\
\hline \multirow[t]{2}{*}{ Text4 } & Pre test & 20 & 0 & 8 & 4 & 2 & 4 \\
\hline & Post test & 20 & 4 & 10 & 7.85 & 1.87153 & 3.503 \\
\hline \multicolumn{8}{|l|}{ Control } \\
\hline \multirow[t]{2}{*}{ Text1 } & Pre test & 20 & 0 & 7 & 3.2 & 1.82382 & 3.326 \\
\hline & Post test & 20 & 1 & 7 & 3.5 & 1.84961 & 3.421 \\
\hline \multirow[t]{2}{*}{ Text2 } & Pre test & 20 & 0 & 8 & 2.6 & 2.25715 & 5.095 \\
\hline & Post test & 20 & 0 & 6 & 2.7 & 1.97617 & 3.905 \\
\hline \multirow[t]{2}{*}{ Text3 } & Pre test & 20 & 0 & 8 & 3.2 & 2.09259 & 4.379 \\
\hline & Post test & 20 & 0 & 8 & 3.3 & 1.97617 & 3.905 \\
\hline \multirow[t]{2}{*}{ Text4 } & Pre test & 20 & 1 & 7 & 3.95 & 1.66938 & 2.787 \\
\hline & Post test & 20 & 1 & 8 & 3.95 & 1.79106 & 3.208 \\
\hline
\end{tabular}

Table 6. Descriptive: Study mean of marks based on education

\begin{tabular}{|c|c|c|c|c|c|c|c|c|}
\hline & \multirow[t]{2}{*}{$\mathbf{N}$} & \multirow[t]{2}{*}{ Mean } & \multirow[t]{2}{*}{$\begin{array}{l}\text { Standard } \\
\text { deviation }\end{array}$} & \multirow[t]{2}{*}{$\begin{array}{c}\text { Standard } \\
\text { error }\end{array}$} & \multicolumn{2}{|c|}{$\begin{array}{l}95 \% \text { confidence } \\
\text { interval for mean }\end{array}$} & \multirow[t]{2}{*}{ Minimum } & \multirow[t]{2}{*}{ Maximum } \\
\hline & & & & & $\begin{array}{l}\text { Lower } \\
\text { bound }\end{array}$ & $\begin{array}{l}\text { Upper } \\
\text { bound }\end{array}$ & & \\
\hline Association degree & 4 & 7.5000 & 1.30703 & 0.65352 & 5.4202 & 9.5798 & 6.25 & 8.75 \\
\hline Bachelor & 10 & 7.8750 & 1.06230 & 0.33593 & 7.1151 & 8.6349 & 6.25 & 9.50 \\
\hline MA & 6 & 7.1667 & 1.09163 & 0.44566 & 6.0211 & 8.3123 & 6.00 & 9.00 \\
\hline Total & 20 & 7.5875 & 1.10404 & 0.24687 & 7.0708 & 8.1042 & 6.00 & 9.50 \\
\hline
\end{tabular}

Table 7. ANOVA

\begin{tabular}{lccccc}
\hline & $\begin{array}{c}\text { Sum of } \\
\text { squares }\end{array}$ & Df & $\begin{array}{c}\text { Mean } \\
\text { square }\end{array}$ & F & Sig. \\
\hline Between groups & 1.920 & 2 & 0.960 & 0.768 & 0.479 \\
Within groups & 21.240 & 17 & 1.249 & & \\
Total & 23.159 & 19 & & & \\
\hline
\end{tabular}

of persons with associate degree Mean $=7.5, \mathrm{SD}=1.3$ and M.A. degree with Mean=7.5, $\mathrm{SD}=1$.
With due attention to the Table 8 , mean of marks of females recorded (7.75) and males (7.1).

According to data of Table 9, in Levene's Test with $\mathrm{F}=0.032$, Sig $>0.05$ shows that equal variance is confirmed, therefore with $\mathrm{T}(18)=1.15$ shows that there is (mean=7.5, $\mathrm{SD}=1.06$ Significant difference among marks of girls and boys.

With due attention to the Table 10, there is a strong correlation between pretest and post test of passage 1(0.816), pretest and post test of passage 3(0.344) and pretest and post 
test of passage $4(0.858)$ in level of 0.05 . This correlation for pretest and post test of passage 2(0.344) is confirmed at average in level of 0.05 .

\section{Check Assumptions}

\section{Check linearity for each group}

In this section to verify the linear Connection between dependent variable (the posttest score) and also covariate them (pretest score) of this graph is used.

As is clear in charts abave Ta linear (straight line) for each group ('Zmaysh and control) in research variables (text1, text2,

Table 8. Group statistics L: Study mean of marks based on gender

\begin{tabular}{lccccc}
\hline & Sex & N & Mean & $\begin{array}{c}\text { Standard } \\
\text { deviation }\end{array}$ & $\begin{array}{c}\text { Standard } \\
\text { error mean }\end{array}$ \\
\hline Test & Girl & 15 & 7.7500 & 1.06066 & 0.27386 \\
& Boy & 5 & 7.1000 & 1.20675 & 0.53968 \\
\hline
\end{tabular}

text 3 , text4) there is, however, to review any the more the slope of the regression were used for each dependent variable.

\section{Check the slope of the regression}

The assumption on the relationship among the dependent variable and also covariate for each of group is concentrated, so check that there is not any interaction among covariate and intervention.

According to what is shown in Table $11-\mathrm{F}(1,36)=2.885$, sig $>0.05$. So interaction (group * text1 pre test) at 0.05 . As a result of this variable was not significant (text1) regression slope assumption is met.

According to what is shown in Table $12-\mathrm{F}(1,36)=2.272$, sig $>0.05$. So interaction (group $*$ text 2 pre test) at 0.05 . As a result of this variable was not significant (text2) regression slope assumption is met.

According to what is shown in Table 13- F $(1,36)=$ 0.918 , sig $>0.05$. So interaction (group $*$ text3 pre test) at 0.05 . As a result of this variable was not significant (text3) regression slope assumption is met.

Table 9. Levene's independent samples test

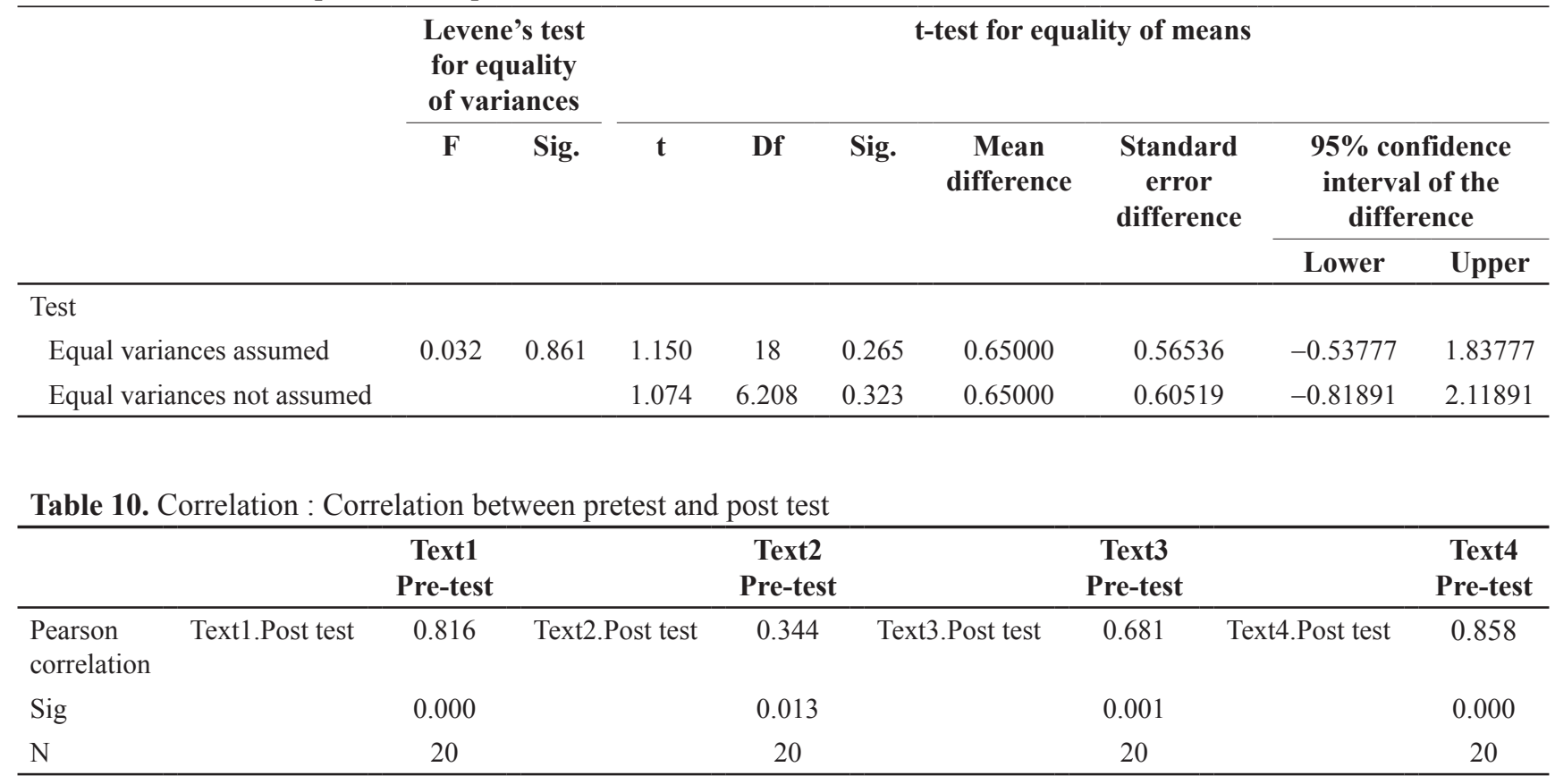

Table 11. Tests among subjects effects for text1

\begin{tabular}{|c|c|c|c|c|c|}
\hline Source & Type III sum of squares & Df & Mean square & $\mathbf{F}$ & Sig. \\
\hline Corrected model & $221.825 \mathrm{a}$ & 3 & 73.942 & 93.154 & 0.000 \\
\hline Intercept & 77.775 & 1 & 77.775 & 97.984 & 0.000 \\
\hline Group & 51.366 & 1 & 51.366 & 64.713 & 0.000 \\
\hline Text1 pre test & 92.096 & 1 & 92.096 & 116.026 & 0.000 \\
\hline Group * text 1 pre test & 2.293 & 1 & 2.293 & 2.889 & 0.098 \\
\hline Error & 28.575 & 36 & 0.794 & & \\
\hline Total & 1374.000 & 40 & & & \\
\hline Corrected total & 250.400 & 39 & & & \\
\hline
\end{tabular}

a.R Squared $=0.886$ (Adjusted R Squared $=0.876$ ) 
According to what is shown in Table 14- F $(1,36)=$ 0.054 , sig $>0.05$. So interaction (group * text4 pre test) at 0.05 . As a result of this variable was not significant (text4) regression slope assumption is met.

\section{The Homogeneity of Variance}

As can be seen in Table 15- significant level of each variable is greater than 0.05 , so Levine test showed that the assumption of homogeneity of the variances was contacted.

\section{Inferential Analysis of Data}

In order To test Null Hypothesis multivariate analysis of the covariance was used.

Hypothesis: Note-taking does not have effect on reading comprehension on Iranian EFL learners.
According to the data of the 16- table:

- Since the test M BOX level is significantly higher than 0.5 so The supposition of homogeneity of variance. The covariance matrix is observed - Bartlett's test -Bartlett's test of sphericity with $\lambda 2=83.14, \mathrm{P}<0.001$ is significant. It shows that there is a relationship Bynmtghyrha -with $\mathrm{F}=0.056, \mathrm{P}$ $<0.01$ Lambda Wilkes multivariate analysis showed that, in general between experimental and control groups at least one of the variables (Test 1 , Test2, Test 3 and Test4) at posttest differences is significant.

As indicated in the above table group is grades and dependent variables Text $1(\mathrm{~F}=176.464$, sig $<0.01)$ with the experimental group's average (1.7) and control (5.3), Text 2 $(\mathrm{F}=128.505, \mathrm{sig}<0.01)$ with an average experimental group (8) and controls (7.2), text $3(\mathrm{~F}=40.715$, sig $<0.01)$ with the experimental group's average (4.7) and control (3.3) and text

Table 12. Tests of between-subjects effects for text 2

\begin{tabular}{|c|c|c|c|c|c|}
\hline Source & Type III sum of squares & Df & Mean square & $\mathbf{F}$ & Sig. \\
\hline Corrected model & $329.307 \mathrm{a}$ & 3 & 109.769 & 48.314 & 0.000 \\
\hline Intercept & 285.197 & 1 & 285.197 & 125.526 & 0.000 \\
\hline Group & 165.201 & 1 & 165.201 & 72.711 & 0.000 \\
\hline Text2pretest & 39.876 & 1 & 39.876 & 17.551 & 0.000 \\
\hline Group * text2pre test & 6.657 & 1 & 6.657 & 2.930 & 0.096 \\
\hline Error & 81.793 & 36 & 2.272 & & \\
\hline Total & 1556.000 & 40 & & & \\
\hline Corrected total & 411.100 & 39 & & & \\
\hline
\end{tabular}

a. $\mathrm{R}$ squared $=0.801$ (Adjusted $\mathrm{R}$ squared $=0.784$ )

Table 13. Tests of between-subjects effects for text3

\begin{tabular}{|c|c|c|c|c|c|}
\hline Source & Type III sum of squares & Df & Mean square & $\mathbf{F}$ & Sig. \\
\hline Corrected model & $305.552 a$ & 3 & 101.851 & 26.657 & 0.000 \\
\hline Intercept & 73.015 & 1 & 73.015 & 19.110 & 0.000 \\
\hline Group & 27.722 & 1 & 27.722 & 7.256 & 0.011 \\
\hline Text3.pre.test & 131.982 & 1 & 131.982 & 34.543 & 0.000 \\
\hline Group * text3.pre.test & 3.509 & 1 & 3.509 & 0.918 & 0.344 \\
\hline Error & 137.548 & 36 & 3.821 & & \\
\hline Total & 1588.000 & 40 & & & \\
\hline Corrected total & 443.100 & 39 & & & \\
\hline
\end{tabular}

a. $\mathrm{R}$ squared $=0.690$ (Adjusted $\mathrm{R}$ squared $=0.664$ )

Table 14. Tests of between-subjects effects for text4

\begin{tabular}{|c|c|c|c|c|c|}
\hline Source & Type III sum of squares & Df & Mean square & $\mathbf{F}$ & Sig. \\
\hline Corrected model & $231.202 \mathrm{a}$ & 3 & 77.067 & 57.325 & 0.000 \\
\hline Intercept & 51.990 & 1 & 51.990 & 38.672 & 0.000 \\
\hline Group & 22.252 & 1 & 22.252 & 16.552 & 0.000 \\
\hline Text4.pre.test & 75.666 & 1 & 75.666 & 56.283 & 0.000 \\
\hline Group * text4.pre.test & 0.072 & 1 & 0.072 & 0.054 & 0.818 \\
\hline Error & 48.398 & 36 & 1.344 & & \\
\hline Total & 1672.000 & 40 & & & \\
\hline Corrected total & 279.600 & 39 & & & \\
\hline
\end{tabular}

a.R squared $=0.827$ (Adjusted $\mathrm{R}$ squared $=0.812$ ) 
$4(\mathrm{~F}=125.522, \operatorname{sig}<0.01)$ with the experimental group's average (8.57) and control (95.3) showed that there is a significant difference in both control and experimental groups. A significant increase in any of texts in experimental group compared to the control means that an increase in comprehension of spoken text notes on students learning a second language in Iran.

\section{DISCUSSION AND CONCLUSION}

Hereon Summary of Findings of the study represent:

The results of ANOVA showed that there is not any significant difference among mean marks of students related to degree (bachelor's degree, MA and associate's degree).

The result of the independent sample t-test proved that there was a statistically significant difference between boys and girls. The result of Pearson correlation also revealed a strong correlation between pretest and post test of passage $1(0.816)$, pretest and post test of passage $3(0.344)$ and pretest and post test of passage $4(0.858)$ in level of 0.05 .This correlation for pretest and post test of passage 2(0.344) was confirmed at average in level of 0.05 .

As a result of multivariate's test, regression slope assumption was met. The Levene's test of Equality of variances also proved that homogeneity of these variances was met as significant. Value was greater than.05.

The present study showed the positive effect of taking note on reading comprehension of Iranian EFL learners. Also finding of this research are consistent with results of previous researches.

The findings of this research are related to those of previous studies which showed taking note is useful to help record reading/lecture information and also they are in line with those of Roy in 2014 who reported that applications of note taking precisely increase the ability of reader in taking note and help them to remember some details and also increase their proficiency in listening, so it is beneficial to be used in language learning classrooms.

Table 15. The levene's test of equality of error variances

\begin{tabular}{lcccc}
\hline & F & Df1 & Df2 & Sig. \\
\hline Text1 post test & 2.003 & 1 & 38 & 0.165 \\
Text2 post test & 0.056 & 1 & 38 & 0.815 \\
Text3 post test & 3.072 & 1 & 38 & 0.088 \\
Text4 post test & 2.391 & 1 & 38 & 0.130 \\
\hline
\end{tabular}

In past years studies show that learning note-taking strategies improve students' reading skills and precisely are useful to make progress in reading tasks of their lessons (O'Malley \& Chamot, 1990; Carrel, 1998; Taraban, 2004; Phakiti, 2006; Motallebzadeh \& Mamdoodi, 2011). For instance, One of the researchers' study show that taking note was useful in remember information of the content and in higher achievement.

The findings, however, contrasts with some studies that discussed about those nonnative speakers that are at a distinct linguistic disadvantages.

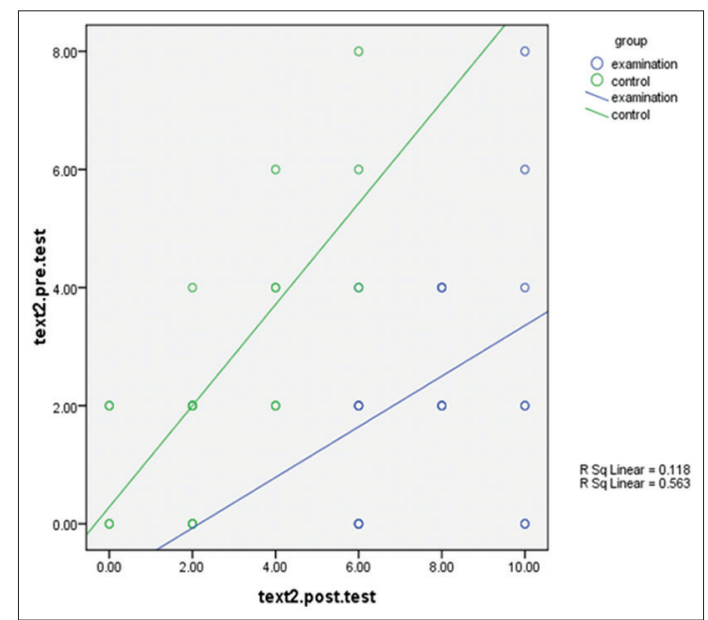

Figure 1. Linear connection among pre and figure 2

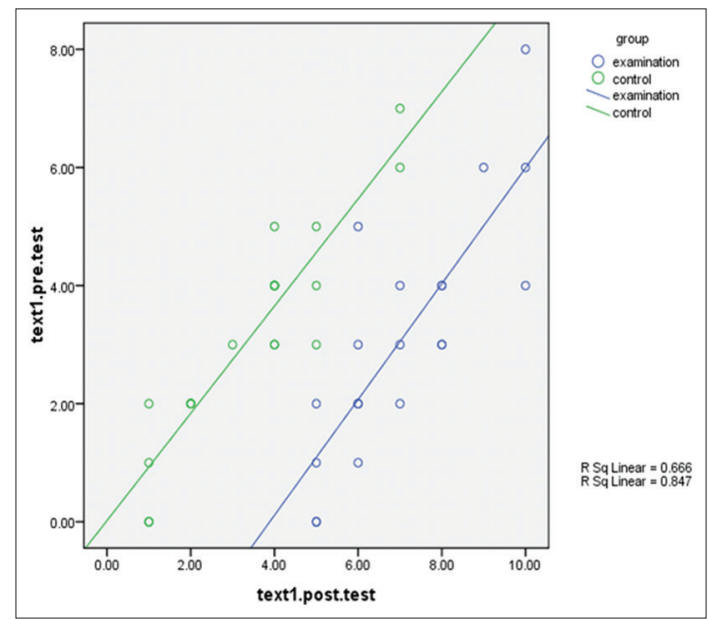

Figure 2. Linear among pretest, posttest and also control groups

Table 16. M BOX, Bartlett's test \& multivariate tests

\begin{tabular}{lccccc}
\hline & Value & F & Df1 & DF2 & Sig \\
\hline Multivariate tests & & & & & \\
M BOX & 6.939 & 0.614 & 10 & 6903.586 & 0.803 \\
Bartlett's test & & $\lambda 2=34.427$ & 9 & 31 & 0.000 \\
Pillai's trace & 0.944 & $131.263 \mathrm{a}$ & 4 & 31 & 0.000 \\
Wilks' Lambda & 0.056 & $131.263 \mathrm{a}$ & 4 & 31 & 0.000 \\
Hotelling's trace & 16.937 & $131.263 \mathrm{a}$ & 4 & 31 & 0.000 \\
Roy's largest root & 16.937 & $131.263 \mathrm{a}$ & 4 & & 0.000 \\
\hline
\end{tabular}


Table 17. Tests of between-subjects effects

\begin{tabular}{|c|c|c|c|c|c|c|c|}
\hline Source & Dependent variable & $\begin{array}{l}\text { Type III sum } \\
\text { of squares }\end{array}$ & Df & Mean square & $\mathbf{F}$ & Sig. & Partial Eta squared \\
\hline \multirow[t]{4}{*}{ Corrected model } & Text1.post.test & 224.681 & 5 & 44.936 & 59.406 & 0.000 & 0.897 \\
\hline & Text2.post.test & 335.068 & 5 & 67.014 & 29.967 & 0.000 & 0.815 \\
\hline & Text3.post.test & 310.272 & 5 & 62.054 & 15.884 & 0.000 & 0.700 \\
\hline & Text4.post.test & 238.822 & 5 & 47.764 & 39.826 & 0.000 & 0.854 \\
\hline \multirow[t]{4}{*}{ Intercept } & Text1.post.test & 33.475 & 1 & 33.475 & 44.254 & 0.000 & 0.566 \\
\hline & Text2.post.test & 49.889 & 1 & 49.889 & 22.309 & 0.000 & 0.396 \\
\hline & Text3.post.test & 22.504 & 1 & 22.504 & 5.760 & 0.022 & 0.145 \\
\hline & Text4.post.test & 46.424 & 1 & 46.424 & 38.708 & 0.000 & 0.532 \\
\hline \multirow[t]{4}{*}{ Text1.pre.test } & Text1.post.test & 53.038 & 1 & 53.038 & 70.116 & 0.000 & 0.673 \\
\hline & Text2.post.test & 12.059 & 1 & 12.059 & 5.392 & 0.026 & 0.137 \\
\hline & Text3.post.test & 6.845 & 1 & 6.845 & 1.752 & 0.194 & 0.049 \\
\hline & Text4.post.test & 0.008 & 1 & 0.008 & 0.006 & 0.936 & 0.000 \\
\hline \multirow[t]{4}{*}{ Text2.pre.test } & Text1.post.test & 1.383 & 1 & 1.383 & 1.828 & 0.185 & 0.051 \\
\hline & Text2.post.test & 29.894 & 1 & 29.894 & 13.368 & 0.001 & 0.282 \\
\hline & Text3.post.test & 0.007 & 1 & 0.007 & 0.002 & 0.967 & 0.000 \\
\hline & Text4.post.test & 0.018 & 1 & 0.018 & 0.015 & 0.903 & 0.000 \\
\hline \multirow[t]{4}{*}{ Text3.pre.test } & Text1.post.test & 3.564 & 1 & 3.564 & 4.711 & 0.037 & 0.122 \\
\hline & Text2.post.test & .001 & 1 & 0.001 & 0.001 & 0.980 & 0.000 \\
\hline & Text3.post.test & 122.223 & 1 & 122.223 & 31.285 & 0.000 & 0.479 \\
\hline & Text4.post.test & 7.417 & 1 & 7.417 & 6.184 & 0.018 & 0.154 \\
\hline \multirow[t]{4}{*}{ Text4.pre.test } & Text1.post.test & 0.304 & 1 & 0.304 & 0.402 & 0.530 & 0.012 \\
\hline & Text2.post.test & 1.846 & 1 & 1.846 & 0.825 & 0.370 & 0.024 \\
\hline & Text3.post.test & 4.591 & 1 & 4.591 & 1.175 & 0.286 & 0.033 \\
\hline & Text4.post.test & 56.298 & 1 & 56.298 & 46.941 & 0.000 & 0.580 \\
\hline \multirow[t]{4}{*}{ Group } & Text1.post.test & 133.483 & 1 & 133.483 & 176.464 & 0.000 & 0.838 \\
\hline & Text2.post.test & 287.368 & 1 & 287.368 & 128.505 & 0.000 & 0.791 \\
\hline & Text3.post.test & 159.062 & 1 & 159.062 & 40.715 & 0.000 & 0.545 \\
\hline & Text4.post.test & 150.544 & 1 & 150.544 & 125.522 & 0.000 & 0.787 \\
\hline \multirow[t]{4}{*}{ Error } & Text1.post.test & 25.719 & 34 & 0.756 & & & \\
\hline & Text2.post.test & 76.032 & 34 & 2.236 & & & \\
\hline & Text3.post.test & 132.828 & 34 & 3.907 & & & \\
\hline & Text4.post.test & 40.778 & 34 & 1.199 & & & \\
\hline
\end{tabular}

Findings of the study indicated That there was a statistically significant difference among mean score of treatment group in the pretest and posttest administration of reading skills in favor of the post administration. This is consistent with the findings of (Marzano, Pickering, \& Pollock, 2001) indicating that effective summarizing and note taking provide the development in student learning. These help students understand the process of information structure which helps in summarization of inputs they receive from text to speech. Those students who can effectively summarize get to a point that they synthesize information, an advanced thinking skill which consist of information analysis, identification of key concepts, and defining additional information. One research in 2000 showed that note taking training is also useful for suc- cessful learning, especially in the use of partial graphic organizers.

The result of that research, although, is not similar to those of Shaw \& McMillion, (2008) who conducted L2 reading research and found that one major obstacle to students in achieving high scores was appeared to be time. Timing affected whether students took notes on terms or not, so lower percentages of students took notes on terms which were further into the text. Non-note-takers did not mark that they were unable to read through the entirety of the text, whereas some note-takers did. A possible explanation for this could be that they did not manage to read the entire text because they were slowed down by note-taking. In this sense, high achieving students who did not take notes more correctly judged the task and, consequently, adopted a more effective 


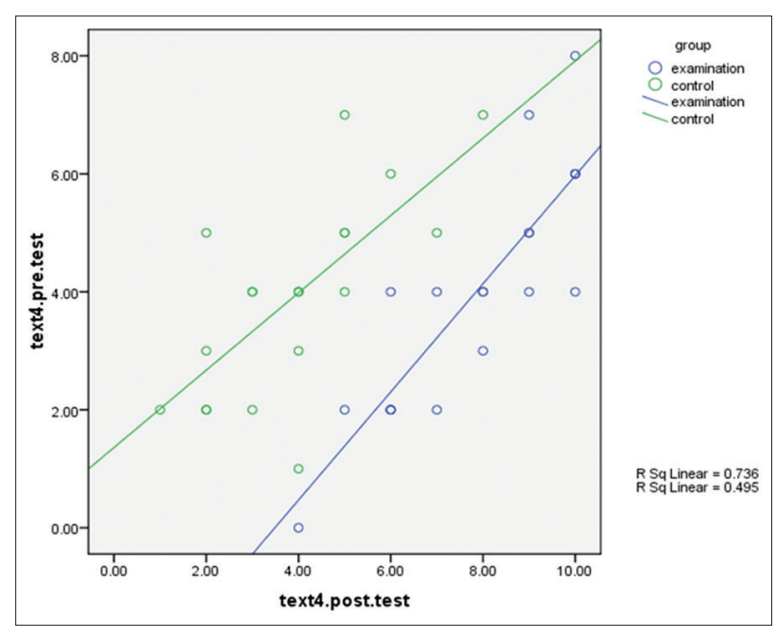

Figure 3. Linear figure 3. Linear connection between pretest and

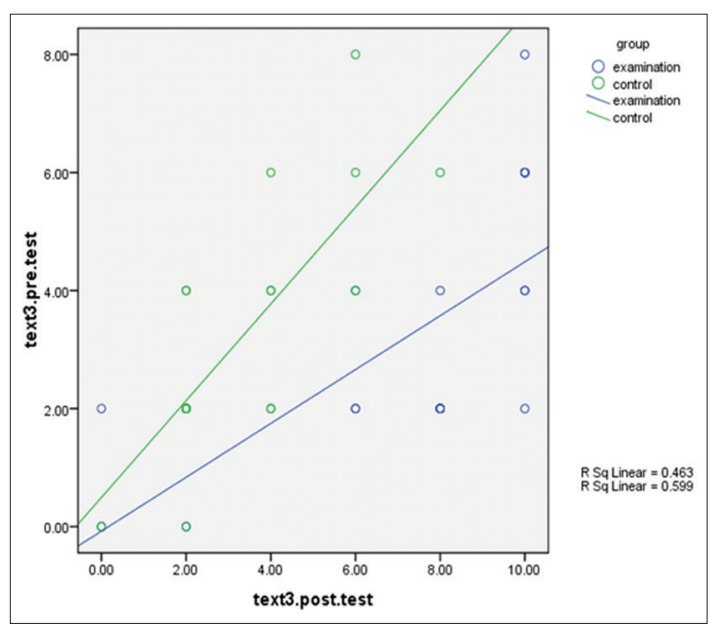

Figure 4. linear connection among pretest, posttest and also control groups

strategy for learning than the note-takers who were unable to finish reading the text, such as the group of unsuccessful learners where almost a third of them marked that they were unable to finish reading the text.

\section{PEDAGOGICAL IMPLICATIONS}

With due attention to the research proved, taking note is useful in reading comprehension; it can encourage teachers and students to focus on this fact that note taking is important and essential and also by teaching this essential strategies of note taking to students, they can see the improvement of proficiency of learners in their reading comprehension. Based on this finding of the study, teachers should teach how effectively students must take note and teachers should add it as part of their learning about the subject matter under instruction in the classroom. Also by learning note taking strategies and taking notes during the reading, student will have progress in their courses and on the whole in their academic life. Students must learn that there are various note taking strategies. One by one each strategy requires different mental tasks which are affected by many factors. Students need to gain the Meta cognitive knowledge which helps them know when, and in what circumstances, which type of note taking strategy is more beneficial. By using spatial note taking modes such as graphic organizers students can take high- quality notes with guidance of their teachers. They should also realize that in the matter of significance not all information is equal. Remembering the important information must be focused more than individual details the focus of teacher on the effectiveness of the strategies of note taking and the overt study behavior of the students must be equal

\section{REFERENCES}

Austin, J. L, Lee, \& Carr, J. P. (2004). The effects of guided notes on undergraduate students' recording of lecture content. Journal of Instructional Psychology, 31(4), 314-320.

Babb, K. A. \& Ross, C (2009). The timing of online lecture slide-availability and its effect on attendance, participation, and exam performance. Computers and Education, 52, 868- 881.

Boch, F. \& Piolat, A. (2005). Note taking and learning: A Summary of research. The WAC Journal, 16, 101-113.

Bonner, J. M., \& Holliday, W. G. (2006). How college science students engage in note-taking strategies. Journal of Research in Science Teaching, 43(8), 786-818.

Carrell, P. L. (1998). Can reading strategies be successfully taught? The Language Teacher (Online), 22(3), 55 Paragraphs.

Carrell PL, Dunkel PA and Mollaun P (2002).The Effects of Note-Taking, Lecture Length and Topic on the Listening Component of the TOEFL 2000 (TOEFL Monograph Series No. MS-23). Princeton, NJ: Educational Testing Service.

Chaudron, C., Loschky, L., \& Cook, J. (1994). Second language listening comprehension and lecture note-taking. In J. Flowerdew (Eds.), Academic listening: Research perspectives (pp. 75-92). Cambridge: CambridgeUniversity Press.

Dewitt, S. (2007). The effects of note taking and mental rehearsal on memory. Journal of Undergraduate Psychological Research, 6(2), 46-49.

Dunkel P (1988). The content of L1 and L2 students lecture notes and its relation to test performance. TESOL Quarterly, 22(2) 259-281.

Einstein, G. O. (1985). Note-taking, Individual Differences, and Memory for Lecture Information. Journal of Educational Psychology, 77(5), 522-532.

Gleason, J. (2012). An investigation of the lecture note-taking skills of adolescents with and without attention deficit/hyperactivity disorder: An extension of previous research. New York City: Teachers College, Columbia University.

Hale, G., \& Courtney, R. (1994). The Effect of Note-Taking on Listening Comprehension inthe Test of English as a Foreign Language. Language Testing, 11, 29-47.

Hartley, J. and I.K. Davies, 1978. Note-taking: A critical review. Programmed Learning and Educational Technology, 15(3), 207-224. 
Helgesen, M., Brown, S., \& Smith, D. (1996). Active listening: Expanding understanding through content. Cambridge, England: Cambridge University Press.

Huang, J. (2006). The Effects of Academic Skills on Chinese ESL Students' Lecture Comprehension. College Student Journal, 40(2), 385-392.

Katayama, A. D., \& Robinson, D. H. (2000). Getting students "partially" involved in note-taking using graphic organizers. Journal of Experimental Education, 68, 119-133.

Kiewra, K. A. (1984). Acquiring effective note-taking skills: an alternative to professional note-taking. Journal of Reading, 27, 299-301.

Kiewra, K. A. (1985). Providing the instructor's notes: An effective addition to student notetaking. Educational Psychologist, 20, 33-39.

Kiewra, k. A. (1987). Notetaking and review: The research in its implication. Instructional Science, 16,233-249.

Kiewra, K. A. (1989). A review of notetaking: The encoding-storage paradigm and beyond. Educational Psychology Review, 3, 147-172.

Kiewra, K.A., \& Benton, S. L.(1988). The relationship between information-processing ability and note-taking. Contemporary Educational Psychology, 13, 33-44.

Kiewra, K. A., DuBois, N. F., Christian, D., McShane, A., Meyerhoffer, M., \& Roskelley, D. (1991). Note-taking functions and techniques. Journal of Educational Psychology, 83, 240-245.

Kiewra, K. A., Benton, S. L., Kim, S., Risch, N., \& Christensen, M. (1995).Effects of note-taking format and study technique on recall and relational performance. Contemporary Educational Psychology, 20(2), 172-187.

Kobayashi, K. (2005). What limits the encoding effect of note-taking? A meta-analytic examination. Contemporary Educational Psychology, 30 (2), 242-262.

Marsh, E. J., \& Sink, H. E. (2010). Access to handouts of presentation slides during lecture: Consequences for learning. Applications of Cognitive Psychology, 24, 691-706.

Marzano, R., Pickering, D., and Pollock, J. (2001). Classroom Instruction that Works: Research-based Strategies for increasing students' achievement. Alexandria, VA: Association for Supervision and Curriculum Development.
Motallebzadeh, K., \& Mamdoodi, N. (2011). Language learning strategies: A key factor to improvement of TOEFLcandidates' reading comprehension ability. International Journal of Linguistics, 3(1), 1-10.

Nakayama, M., K. Mutsuura and H. Yamamoto, 2011. Evaluation of student's notes in a blended learning course. International Journal on New Computer Architectures and Their Applications, 1(4), 1056-1065.

O’Malley, M. J., \& Chamot, A. U. (1990). Learning strategies in second language acquisition. Cambridge: Cambridge University Press.

Peverly, S. T., Brobst, K., Graham, M., \& Shaw, R. (2003). College adults are not good at self-regulation: A study on the relationship of self-regulation, notetaking, and test-taking. Journal of Educational Psychology, 95, 335-346.

Peverly, S. T., Ramaswamy, V., Brown, C., Sumowski, J., Alidoost, M., \& Garner, J. (2007). What predicts skill in lecture note taking? Journal of Educational Psychology,99(1), 167-180.

Phakiti, A. (2006). Modeling cognitive and metacognitive strategies and their relationship to EFL reading test performance. Melborn Papers in Language Testing, 1, 53-95.

Piolat, A., Olive, T., \& Kellogg R.T. (2005). Cognitive effort of note taking. Applied Cognitive Psychology, 19, 291-312.

Raver, S.A. \& Maydosz, A.S. (2010). Impact of the provision and timing of instructor- provided notes on university students' learning. Active Learning in Higher Education, 11(3), $189-200$.

Roy, D., Brine, J., \& Murasawa, F. (2014). Usability of English note-taking applications in a foreign language learning context. Computer Assisted Language Learning, 29(1), 1- 27.

Shaw, P., and McMillion, A. (2008). Proficiency Effects and Compensation in Advanced Second-language Reading. NordicJournal of English Studies, 7(3), 123-143.

Taraban, R., Kerr, M., RyNearson, K. (2004). Analytic and pragmatic factors in college students' metacognitive reading strategies. ReadingPsychology, 25 (2), 67-81.

Vekaria, P. C. (2011). Lecture note-taking in postsecondary students with self-reported attention-deficit/hyperactivity disorder. New York City: Teachers College, Columbia University. 